J. Asiat. Soc. Bangladesh, Sci. 40(1): 141-150, June 2014

\title{
INTERACTION EFFECTS OF ARSENIC AND PHOSPHORUS ON SEEDLING GROWTH, LEAF PIGMENTS AND LEAF PROTEIN OF RICE CULTIVARS UNDER HYDROPONIC CULTURE
}

\author{
M. A. HALIM ${ }^{1}$, MEHER NIGER, MOITRY GHOSH, NAHID AKHTER \\ AND FEROZA HOSSAIN \\ Plant Physiology and Biochemistry laboratory, Botany Department, \\ Jahangirnagar University, Dhaka-1342, Bangladesh
}

\begin{abstract}
Present study was conducted to evaluate the effect of arsenic and its interaction with phosphorus (P) on root and shoot growth, chlorophyll contents and leaf protein at seedling stage under hydroponic culture. Three cultivars of rice BR-26, BR-3 and BRRI45 were used in this study. Arsenate significantly reduced root and shoot growth and chlorophyll content in all the cultivars. However leaf protein increased in BR-26, BR-3 and reduced in BRRI-45. Combined treatment of As and P significantly increased root and shoot length. Significant reduction of As toxicity was observed in hydroponic rice cultivars treated with As and P together. It may be said that $\mathrm{P}$ plays a vital role in the reduction of As contamination of rice and the results show that BR-26 is relatively tolerant to arsenate with respect to the root-shoot growth and leaf protein.
\end{abstract}

Key words: Arsenic, Phosphorus, Rice, Root length, Shoot length, Leaf pigment, Leaf protein

\section{Introduction}

Arsenic (As) contamination of groundwater is a severe problem in Bangladesh and it has affected at least 25 million people (Ravenscroft et al. 2005). Next to drinking water, rice could be a potential source of As exposure to the people living in the As affected areas of Bangladesh (Hossain et al. 2008 and Panaullah et al. 2009). Roberts et al.(2007) estimated that over 1000 tons of As might be transferred to arable land each year through As contaminated groundwater irrigation, creating a potential risk for future agricultural sustainability and food security of the country. People of Bangladesh not only drink the As contaminated groundwater, they also irrigatie their crops (mainly rice) with it mostly in the Boro season. Long term use of As contaminated water for irrigation may result in the elevation of As concentration in soils and plants (Ullah 1998 and Haq et al. 2003). Normal irrigated soils in Bangladesh contain 4-8 mg As kg${ }^{-1}$ while soils irrigated with As contaminated water contain up to $83 \mathrm{mg} \mathrm{As} \mathrm{kg}^{-1}$ (Ullah 1998).

Arsenate uptake and toxicity/tolerance have been well characterized in plants (HartleyWhitaker et al. 2001). Plants can develop toxicity symptoms such as: inhibition of seed

\footnotetext{
${ }^{1}$ Corresponding author: Email: mahalim21@yahoo.com
} 
germination (Abedin and Meharg 2002); decrease in plant height (Marin et al, 1992, Carbonel-Barrachina et al. 1995, Abedin et al. 2002b and Jahan et al. 2003a); depressed tillering (Kang et al. 1996 and Rahman et al. 2004); reduction in root growth (CarbonelBarrachina et al. 1998 and Abedin et al. 2002); decrease in shoot growth (Cox et al. 1996 and Carbonel-Barrachina et al. 1998); lower fruit and grain yield (Carbonel-Barrachina et al. 1995, Kang et al. 1996 and Abedin et al. 2002b) and reduction in photosynthesis rate (Miteva and Merakehiyska, 2002) while they are exposed to excess As either in soil or in solution culture. Arsenate the dominant form of As in aerobic conditions is taken up by plants via the phosphate transport systems because of the chemical similarity between arsenate and phosphate (Dixon 1997). Phosphorus is a chemical analogue of As (Adriano 2001) which competes with As in plant uptake (Meharg and Macnair 1992), is one of essential elements for plant growth (Raghothama 1999). The effect of $P$ on the absorption of As in soil environments has received great attention, especially when $\mathrm{P}$ is used as a crop fertilizer (Peryea 1998). Phosphorus fertilizer is common in rice cultivation which might interact with As uptake (Qafoku et al. 1999). In rice seedlings, cultivars found to be susceptible to arsenate and become more resistant by raising level of intracellular $\mathrm{P}$ (Geng et al. 2006 and Wang and Duan 2009).

Arsenic contamination in rice has become a serious problem, and it is therefore, urgent to develop strategies to minimize As accumulation or toxicity in rice plants. With this in view hydroponic culture of some rice cultivars was used to study the effect of arsenatephosphorus interaction on seedling growth, chlorophyll content and protein content in leaf at early seedling stage of rice.

\section{Materials and Methods}

Rice cultivars: Based on the previous knowledge (Ghosh 2011) on germination and seedling growth three cultivars of rice were chosen for the present study. The cultivars collected from Bangladesh Rice Research Institute (BRRI) were BR-26, BR-3 and BRRI45 .

Treatments: Following Islam and Jahiruddin (2010) a total of nine treatments of which two concentrations were sodium arsenate $\left(\mathrm{Na}_{2} \mathrm{HAsO}_{4} \cdot 7 \mathrm{H}_{2} \mathrm{O}\right)$ solution, such as $\mathrm{T}_{1}=6 \mathrm{ppm}$ and $\mathrm{T}_{2}=12 \mathrm{ppm}$ As, six were mixed sodium arsenate and phosphate (source $\mathrm{KH}_{2} \mathrm{PO}_{4}$ ) solutions eg., $\mathrm{T}_{0} \mathrm{P}_{1}=0 \mathrm{ppm}(\mathrm{As})$ and $31 \mathrm{ppm}(\mathrm{P}), \mathrm{T}_{0} \mathrm{P}_{2}=0 \mathrm{ppm}(\mathrm{As})$ and $62 \mathrm{ppm}(\mathrm{P})$, $\mathrm{T}_{1} \mathrm{P}_{1}=6 \mathrm{ppm}(\mathrm{As})$ and $31 \mathrm{ppm}(\mathrm{P}), \mathrm{T}_{1} \mathrm{P}_{2}=6 \mathrm{ppm}(\mathrm{As})$ and $62 \mathrm{ppm}(\mathrm{P}), \mathrm{T}_{2} \mathrm{P}_{1}=12 \mathrm{ppm}$ (As) and $31 \mathrm{ppm}(\mathrm{P}), \mathrm{T}_{2} \mathrm{P}_{2}=12 \mathrm{ppm}(\mathrm{As})$ and $62 \mathrm{ppm}(\mathrm{P})$ and one of distilled water was used as the control.

Seedling culture: The seedling growth experiment was conducted by hydroponic cultures under semi laboratory condition. On the emergence of the radicals, 5 germinated seeds were placed in the hole of plastic nets attached with cork sheets all around the net. These materials are round in shapes which were then placed on the mouth of a $250 \mathrm{ml}$ plastic pot. The outside of the plastic pots were painted with black colour. The pots were filled with $250 \mathrm{ml}$ of nutrient solution composed of $5 \mathrm{mM} \mathrm{Ca}\left(\mathrm{NO}_{3}\right)_{2}, 5 \mathrm{mM} \mathrm{KNO} 3,5 \mathrm{mM}$ 
$\mathrm{K}_{2} \mathrm{SO}_{4}$ and $5 \mathrm{mM} \mathrm{KH} \mathrm{KH}_{4}$ in distilled water (Abbas and Meharg 2008). The plants were grown hydroponically in these pots. Deep colour plastic beads were added at the upper portion of each pot to prevent the light from penetrating the solution. The nutrient solutions were contaminated with the treatments mentioned in section treatments separately. The $\mathrm{pH}$ was adjusted to 5 . For each treatment three replications were used. The plastic pots with germinated rice seedlings were then placed at room temperature $\left(30^{\circ} \mathrm{C}\right)$ for 15 days. The solutions of the growth media were renewed every week. The seedlings were collected and washed with distilled water on15 DAT (Days after treatment). Shoots and roots were separated and root length and shoot length of growing seedlings were measured.

Quantitative determination of leaf pigment: Chlorophyll a and chlorophyll b content of leaves were determined from the samples of the control, arsenate treatments and arsenatephosphate interaction treatments. The leaf pigments were determined from 10 day old plants. The analysis of pigments was determined spectrophotometrically. Leaf materials were cut into small pieces and mixed thoroughly. One gm of fresh leaf was smashed finely in a mortar and made into paste with $100 \mathrm{ml}$ of cold $80 \%$ acetone. The homogenate was filtered through Whatman No. 1 filter paper. The final volume of the mixture was made $100 \mathrm{ml}$ by adding extra acetone. The optical density (OD) for each solution was measured at 663 and $645 \mathrm{~nm}$ against 80\% acetone as blank. Specific absorption coefficient method of Mckinney (1940) and the formula of Machlachalan and Zalik (1963) were used to determine the amount of chlorophyll-a and chlorophyll-b as $\mathrm{mg} / \mathrm{g}$ fresh leaf.

Quantitative determination of leaf protein: Using the method of Lowry et al. (1951) soluble protein content of fresh leaves of seedlings was determined for each treatment at the growth stage. The water soluble leaf protein was extracted by smashing $0.1 \mathrm{gm}$ of coarsely chopped leaf tissue with $10 \mathrm{ml}$ of distilled water in a mortar with a pestle. The homogenate was rapidly filtered in Whatman No.1 filter paper and the filtrate was used for protein assay. The protein solution was measured at $650 \mathrm{~nm}$ by using UV spectrophotometer (Unicum) and the amount of protein was determined by comparing with a standard curve prepared from known amounts of bovine albumin (BDH, England).

Statistical analysis: Completely randomized design (CRD) was used for the experiment. Recorded data were analyzed with using SPSS 16.0 program and results are compared by least significance difference test (LSD Test) at 5\% probability level (Gomez and Gomez 1984). Increases or decreases of leaf protein percentage at different treatments were calculated by taking the protein content in control plant as $100 \%$.

\section{Results and Discussion}

Root length: Root growth of three cultivars of rice is presented in Table 1. Significant differences in results (at 5\% probability level) were observed among the treatments. The longest root length was found for the control plants in all cultivars, e.g., $121.7 \mathrm{~mm}$ for BR-26, $106.5 \mathrm{~mm}$ for BR-3 and $88 \mathrm{~mm}$ for BRRI-45, whereas for the highest As treatment $\left(\mathrm{T}_{2}=12 \mathrm{ppm} \mathrm{As}\right)$, shortest root length was found in all cultivars, e.g., $38 \mathrm{~mm}$ for BR-26, $29.5 \mathrm{~mm}$ for BR-3 and $28.2 \mathrm{~mm}$ for BRRI-45 (Table 1). The significant effects of combined arsenate-phosphorus were found for $\mathrm{T}_{1} \mathrm{P}_{1}$ and $\mathrm{T}_{2} \mathrm{P}_{2}$. At $\mathrm{T}_{2} \mathrm{P}_{2}$ (highest 
concentration of As and P) treatments such that the root lengths $60.3 \mathrm{~mm}$ for BR-26, 43.3 $\mathrm{mm}$ for BR-3 and $40.90 \mathrm{~mm}$ for BRRI-45, which are longer than that of the root length for $\mathrm{T}_{2}$ (highest concentration of As) treatment. The mean root length for $\mathrm{T}_{2}$ treatment was $31.9 \mathrm{~mm}$, whereas that for $\mathrm{T}_{2} \mathrm{P}_{2}$ was $48.17 \mathrm{~mm}$, which is $51 \%$ higher than $\mathrm{T}_{2}$ treatment. The mean root length decreased from $105.4 \mathrm{~mm}$ for the control to $31.9 \mathrm{~mm}$ for $\mathrm{T}_{2}(12 \mathrm{ppm}$ of As) and increased to $77.43 \mathrm{~mm}$ for $\mathrm{T}_{2} \mathrm{P}_{1}(12 \mathrm{ppm}$ As and 31ppm P). Among all cultivars for all the treatments it was observed that BR-26 produced relatively the longest root followed by BR-3, while BRRI-45 produced the shortest root. From the CV (\%), it can be said that the root length of BRRI-45 was more scattered and BR-3 was more homogeneous (Table 1). The results also show that the control plants produced the longest root length, whereas only As treated plants formed shortest root length and when the plants were treated with both the As and P, root growth was increased over the arsenic treated plants for all cultivars. This result indicates that the $\mathrm{P}$ inhibits the toxicity of As in rice cultivars and also induces the root growth in the presence of As. The result of the present study agrees well with those of Shaibur et al. (2013) and Sneller et al. (1999).

Table 1. Effect of sodium arsenate and phosphate interaction on root length $(\mathrm{mm})$ of three rice cultivars.

\begin{tabular}{c|c|c|c|c|c|c}
\hline \multicolumn{3}{c|}{ Treatments } & \multicolumn{3}{c|}{ Cultivars } & $\begin{array}{c}\text { Treatment } \\
\text { means }\end{array}$ \\
\cline { 1 - 5 } & $\begin{array}{c}\text { Arsenate } \\
(\mathrm{ppm})\end{array}$ & $\begin{array}{c}\text { Phosphate } \\
(\mathrm{ppm})\end{array}$ & BR26 & BR 3 & BRRI 45 & \\
\hline $\mathrm{T}_{0}$ & 0 & 0 & 121.70 & 106.50 & 88.00 & 104.40 \\
$\mathrm{~T}_{1}$ & 6 & 0 & 54.20 & 38.9 & 36.30 & 43.13 \\
$\mathrm{~T}_{2}$ & 12 & 0 & 38.00 & 29.50 & 28.20 & 31.90 \\
$\mathrm{~T}_{0} \mathrm{P}_{1}$ & 0 & 31 & 123.60 & 73.10 & 101.20 & 99.30 \\
$\mathrm{~T}_{0} \mathrm{P}_{2}$ & 0 & 62 & 109.60 & 63.90 & 72.00 & 81.83 \\
$\mathrm{~T}_{1} \mathrm{P}_{1}$ & 6 & 31 & 82.50 & 61.20 & 46.40 & 63.37 \\
$\mathrm{~T}_{1} \mathrm{P}_{2}$ & 6 & 62 & 92.10 & 76.70 & 63.50 & 77.43 \\
$\mathrm{~T}_{2} \mathrm{P}_{1}$ & 12 & 31 & 52.20 & 37.90 & 26.80 & 38.97 \\
$\mathrm{~T}_{2} \mathrm{P}_{2}$ & 12 & 62 & 60.30 & 43.30 & 40.90 & 48 \\
Cultivars & & & 81.00 & 59.00 & 55.92 & \\
mean & & & & & & \\
LSD at & & & 5.63 & 5.02 & 5.79 & \\
$5 \%$ & & & & & \\
CV \% & & & 42.01 & 45.89 & 53.79 & \\
\hline
\end{tabular}

Shoot Length: Shoot length was recorded 15 days after the hydroponic culture. The longest shoot length was found for the control plants in all cultivars, e.g., $128.70 \mathrm{~mm}$ for BR 26, $162.20 \mathrm{~mm}$ for BR 3 and $171.00 \mathrm{~mm}$ for BRRI 45, whereas for the highest sodium arsenate treatment $\left(\mathrm{T}_{2}\right)$, the shortest shoot length was found in all the cultivars, e.g., $74.40 \mathrm{~mm}$ for BR 26, $66.00 \mathrm{~mm}$ for BR 3 and $58.20 \mathrm{~mm}$ for BRRI 45 (Table 2). The 
significant effect of arsenate-phosphorus was found for the treatment $\mathrm{T}_{1} \mathrm{P}_{2}$, where the shoot lengths have $103.4 \mathrm{~mm}$ for BR 26, $115.8 \mathrm{~mm}$ for BR 3 and $77.9 \mathrm{~mm}$ for BRRI 45, which were $38.98,75.45$ and $34.31 \%$ increase respectively over that of $\mathrm{T}_{2}$ treatment (highest As level). Treatment mean of shoot length was decreased gradually from 153.97 for the control treatment to $66.2 \mathrm{~mm}$ for $\mathrm{T}_{2}$ (12ppm As), whereas shoot length increased from $66.2 \mathrm{~mm}$ for Control treatment to $84.17 \mathrm{~mm}$ for $\mathrm{T}_{2} \mathrm{P}_{2}(12 \mathrm{ppm}$ As and $62 \mathrm{ppm} \mathrm{P})$, which was $27.15 \%$ higher than the $\mathrm{T}_{2}$ treatment. From the CV (\%) it is found that the shoot lengths of BRRI 45 are more scattered and the shoot lengths of BR 26 are more homogeneous (Table 2). P has a significant effect on the shoot growth. The combined effects of As and $\mathrm{P}$ on the growth of shoot length were found significant at $5 \%$ probability level. The results of the present study showed that the cultivar BR 26 produced the longest shoot for the combined treatment $12 \mathrm{ppm}$ As and $62 \mathrm{ppm} \mathrm{P}$ except for the control. It can then be said that $62 \mathrm{ppm} P$ treatment can reduce the toxicity of As better when rice grown in As contaminated media. Sharma and Travlos (2012) suggested that increased supply of phosphate provided protection to the plant system and the effect of phosphate appears in the form of a reduced amount of growth inhibition during arsenic toxicity.

Table 2. Effect of sodium arsenate and phosphate interaction on shoot length $(\mathrm{mm})$ of three rice cultivars.

\begin{tabular}{c|c|c|c|c|c|c}
\hline \multicolumn{3}{c|}{ Treatments } & \multicolumn{3}{c|}{ Cultivars } & $\begin{array}{c}\text { Treatment } \\
\text { means }\end{array}$ \\
\hline & $\begin{array}{c}\text { Arsenate } \\
(\mathrm{ppm})\end{array}$ & $\begin{array}{c}\text { Phosphate } \\
(\mathrm{ppm})\end{array}$ & BR 26 & BR 3 & $\begin{array}{c}\text { BRRI } \\
45\end{array}$ & \\
\hline $\mathrm{T}_{0}$ & 0 & 0 & 128.70 & 162.20 & 171.00 & 153.97 \\
$\mathrm{~T}_{1}$ & 6 & 0 & 94.50 & 71.10 & 74.20 & 79.93 \\
$\mathrm{~T}_{2}$ & 12 & 0 & 74.40 & 66.00 & 58.20 & 66.2 \\
$\mathrm{~T}_{0} \mathrm{P}_{1}$ & 0 & 31 & 115.90 & 148.40 & 130.00 & 131.43 \\
$\mathrm{~T}_{0} \mathrm{P}_{2}$ & 0 & 62 & 110.40 & 102.00 & 128.70 & 113.7 \\
$\mathrm{~T}_{1} \mathrm{P}_{1}$ & 6 & 31 & 101.50 & 104.60 & 61.00 & 89.03 \\
$\mathrm{~T}_{1} \mathrm{P}_{2}$ & 6 & 62 & 103.40 & 115.80 & 77.90 & 99.03 \\
$\mathrm{~T}_{2} \mathrm{P}_{1}$ & 12 & 31 & 87.00 & 79.50 & 73.30 & 79.33 \\
$\mathrm{~T}_{2} \mathrm{P}_{2}$ & 12 & 62 & 93.30 & 82.30 & 76.90 & 84.17 \\
Cultivars & & & 101.01 & 103.54 & 94.58 & \\
mean & & & & & & \\
LSD at 5\% & & & 7.07 & 9.99 & 6.54 & \\
CV \% & & & 24.80 & 41.04 & 43.63 & \\
\hline
\end{tabular}

Chlorophyll content: Chlorophyll content in leaves of early seedling was measured after 11days of growth. Chlorophyll-a, chlorophyll-b and total chlorophyll of three cultivars of rice are presented in Table 3. Highest chlorophyll-a and chlorophyll-b contents were found in rice cultivar BR 45 for the control plants. The mean value of chlorophyll-a and chlorophyll-b contents decreased for both As and combined As and P treated seedlings of 
BR 26 and BR 3. The chlorophyll content decreased significantly with the increase of arsenate concentration in all the cultivars. Beside these, the chlorophyll-a, chlorophyll-b and total chlorophyll increased in seedlings of BRRI 45 for the combined treatments of $\mathrm{T}_{1} \mathrm{P}_{1}$ and $\mathrm{T}_{1} \mathrm{P}_{2}$ compared with the As treatments $\mathrm{T}_{1}$ and $\mathrm{T}_{2}$ (Table 3). However the chlorophyll content and increasing or decreasing tendencies of chlorophyll content varied within the cultivars and also for the different treatments. The chlorophyll content was found to increase in BRRI 45 for the combined As and $\mathrm{P}$ treatments $\mathrm{T}_{1} \mathrm{P}_{1}$ and $\mathrm{T}_{1} \mathrm{P}_{2}$ compared to $T_{2}$ treatment.Van and Clijsters (1990) suggested that the protochlorophyllide reductase activity was inhibited by heavy metal. Chlorophyll content was decreased by As treatment, because heavy metal entered in leaves and accumulated excessively in some parts and combined with $-\mathrm{SH}$ base of protein or substituted for $\mathrm{Fe}^{2+}, \mathrm{Zn}^{2+}, \mathrm{Mg}^{2+}$ and so on and then destroyed the structure and function of chloroplast. Thus the high concentration of heavy metals, chlorophyll content in plants decreases. The decreasing tendency of chlorophyll found in present study for As treated seedlings agrees well with the findings of Van and Clijsters (1990).

Table 3. Arsenate-phosphorus interaction effect on chlorophyll content of rice seedlings at hydroponic culture.

\begin{tabular}{|c|c|c|c|c|c|c|c|}
\hline \multirow[t]{2}{*}{ Cultivars } & \multirow[t]{2}{*}{ Treatments } & \multirow{2}{*}{$\frac{\text { Chlorophyll- }}{\mathrm{mg} / \mathrm{g}}$} & \multirow{2}{*}{$\begin{array}{l}\text { a content } \\
\text { Relative } \\
\% \text { (over } \\
\text { control) }\end{array}$} & \multicolumn{2}{|c|}{ Chlorophyll- b content } & \multirow{2}{*}{$\begin{array}{l}\text { Total } \\
\mathrm{mg} / \mathrm{g}\end{array}$} & \multirow{2}{*}{$\begin{array}{l}\text { Chlorophyll } \\
\begin{array}{|l}\text { Relative } \\
\% \text { (over } \\
\text { control) }\end{array}\end{array}$} \\
\hline & & & & $\mathrm{mg} / \mathrm{g}$ & $\begin{array}{l}\text { Relative } \\
\% \text { (over } \\
\text { control) }\end{array}$ & & \\
\hline \multirow{9}{*}{ BR 26} & $\mathrm{~T}_{0}$ & 0.791 & 100 & 0.421 & 100 & 1.212 & 100 \\
\hline & $\mathrm{T}_{1}$ & 0.579 & 73.23 & 0.289 & 68.51 & 0.868 & 71.59 \\
\hline & $\mathrm{T}_{2}$ & 0.285 & 36.05 & 0.144 & 34.26 & 0.429 & 35.42 \\
\hline & $\mathrm{T}_{0} \mathrm{P}_{1}$ & 0.186 & 23.44 & 0.097 & 23.02 & 0.282 & 23.29 \\
\hline & $\mathrm{T}_{0} \mathrm{P}_{2}$ & 0.185 & 19.98 & 0.064 & 15.19 & 0.222 & 18.31 \\
\hline & $\mathrm{T}_{1} \mathrm{P}_{1}$ & 0.199 & 25.17 & 0.077 & 18.20 & 0.276 & 22.74 \\
\hline & $\mathrm{T}_{1} \mathrm{P}_{2}$ & 0.208 & 26.26 & 0.087 & 20.81 & 0.295 & 24.37 \\
\hline & $\mathrm{T}_{2} \mathrm{P}_{1}$ & 0.165 & 20.87 & 0.072 & 17.17 & 0.237 & 19.58 \\
\hline & $\mathrm{T}_{2} \mathrm{P}_{2}$ & 0.175 & 22.13 & 0.096 & 22.86 & 0.271 & 22.39 \\
\hline \multirow{9}{*}{ BR 3} & $\mathrm{~T}_{0}$ & 0.992 & 100 & 0.379 & 100 & 1.371 & 100 \\
\hline & $\mathrm{T}_{1}$ & 0.874 & 88.10 & 0.167 & 44.06 & 1.041 & 75.93 \\
\hline & $\mathrm{T}_{2}$ & 0.654 & 65.89 & 0.154 & 40.81 & 0.808 & 58.96 \\
\hline & $\mathrm{T}_{0} \mathrm{P}_{1}$ & 0.861 & 86.79 & 0.374 & 98.68 & 1.235 & 90.08 \\
\hline & $\mathrm{T}_{0} \mathrm{P}_{2}$ & 0.53 & 53.43 & 0.263 & 69.31 & 0.793 & 57.82 \\
\hline & $\mathrm{T}_{1} \mathrm{P}_{1}^{2}$ & 0.291 & 29.33 & 0.143 & 37.73 & 0.434 & 31.66 \\
\hline & $\mathrm{T}_{1} \mathrm{P}_{2}$ & 0.317 & 31.96 & 0.176 & 46.44 & 0.493 & 35.96 \\
\hline & $\mathrm{T}_{2} \mathrm{P}_{1}$ & 0.175 & 17.64 & 0.153 & 40.37 & 0.328 & 23.92 \\
\hline & $\mathrm{T}_{2} \mathrm{P}_{2}$ & 0.298 & 30.04 & 0.168 & 44.42 & 0.466 & 34.01 \\
\hline \multirow{9}{*}{ BRRI 45} & $\mathrm{~T}_{0}$ & 1.136 & 100 & 0.742 & 100 & 1.878 & 100 \\
\hline & $\mathrm{T}_{1}$ & 0.548 & 48.23 & 0.355 & 47.87 & 0.903 & 48.08 \\
\hline & $\mathrm{T}_{2}$ & 0.214 & 18.83 & 0.144 & 19.37 & 0.358 & 19.01 \\
\hline & $\mathrm{T}_{0} \mathrm{P}_{1}$ & 1.244 & 109.47 & 0.665 & 89.76 & 1.910 & 101.69 \\
\hline & $\mathrm{T}_{0} \mathrm{P}_{2}$ & 0.992 & 87.30 & 0.505 & 68.18 & 1.498 & 79.75 \\
\hline & $\mathrm{T}_{1} \mathrm{P}_{1}$ & 0.782 & 68.82 & 0.420 & 56.63 & 1.202 & 64.00 \\
\hline & $\mathrm{T}_{1} \mathrm{P}_{2}$ & 0.879 & 77.35 & 0.492 & 66.34 & 1.371 & 73.00 \\
\hline & $\mathrm{T}_{2} \mathrm{P}_{1}$ & 0.287 & 25.29 & 0.089 & 11.96 & 0.376 & 20.02 \\
\hline & $\mathrm{T}_{2} \mathrm{P}_{2}$ & 0.542 & 47.73 & 0.263 & 35.46 & 0.805 & 42.88 \\
\hline
\end{tabular}

Note: Data are the average value of three replicates. Relative percentage of chlorophyll $\mathrm{a}, \mathrm{b}$ and total chlorophyll was calculated by taking the chlorophyll content in control plant as $100 \%$. 
Protein content: The results of protein content in fresh leaves of early seedlings (11 days after growth) at different concentrations of As and As-P treatments of three cultivars are presented in the (Figs.1 and 2). An interesting result is found that the protein contents in leaves increased in BR 26 and BR 3, but slightly decreased in BRRI 45 for the As treatment $\mathrm{T}_{2}$. For the combined treatment $\mathrm{T}_{2} \mathrm{P}_{2}$ the total protein content $22.187 \mathrm{mg} / \mathrm{g}$ were found for BR 26, $24.201 \mathrm{mg} / \mathrm{g}$ for BR 3 and $28.567 \mathrm{mg} / \mathrm{g}$ fresh leaf for BRRI 45 which were lower than that of $\mathrm{T}_{2}$ treatment. It was also observed that the protein content of BRRI 45 was decreased by both sodium arsenate and As-P treatments (Fig. 2). In the present study it was found that the protein content of rice cultivar BR 26 and BR 3 has an increasing tendency with the increase of As concentration but it turned to a decreasing tendency for BRRI 45. The soluble protein content in plant cells is an indicator for their physiological state. The growth of plants was inhibited by arsenate treatment and the protein content that was not used, was accumulated in cells and this caused the increased of soluble protein (Yu et al. 1995).

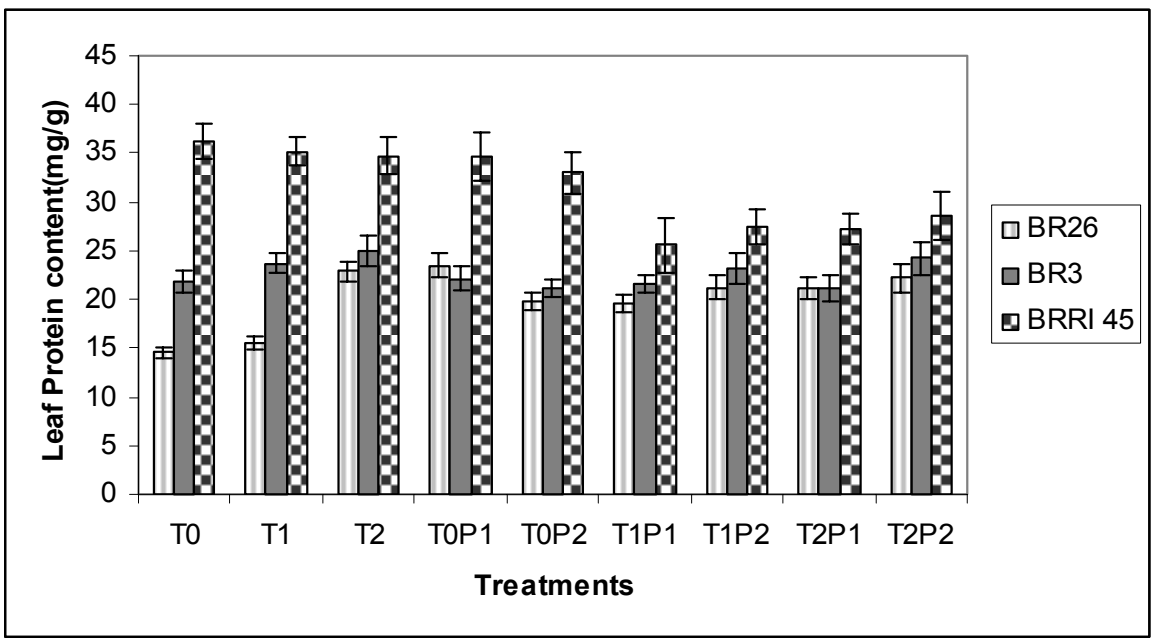

Fig.1. Effect of sodium arsenate and arsenic-phosphorus interaction on seedling leaf protein of three rice cultivars grown in hydroponic culture. 


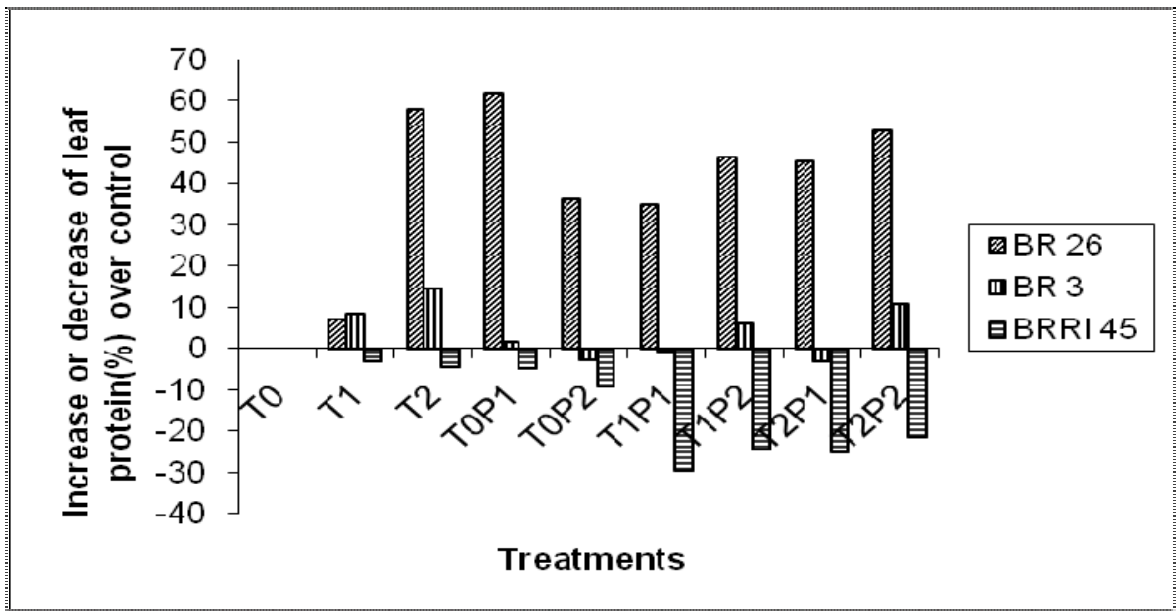

Fig. 2. Leaf protein percentage increases or decreases over control for different levels of arsenic and phosphorus of three rice cultivar.

In conclusion it may be said that heavy metal As inhibits root, shoot growth and chlorophyll synthesis of rice cultivars severely but leaf protein content increased in As treated rice cultivars, BR 26 and BR 3. Macro nutrient $\mathrm{P}$ plays an important role for reducing the toxicity of As and it provokes to increase the root and shoot growth of As treated rice cultivars. In the present study it is found that rice cultivar BR 26 seems to be As tolerant considering the root-shoot growth and leaf protein.

\section{References}

Abbas, H.H.M. and A.A. Meharg. 2008. Arsenate, arsenite and dimethyl arsenic acid (DMA) uptake and tolerance in maize (Zea mays L.). Plant Soil. 304:277-289.

Abedin, M.J. and A.A. Meharg. 2002. Relative toxicity of arsenite and arsenate on germination and early seedling growth of rice (Oryza sativa L.). Plant Soil. 243:57-66.

Abedin, M.J., J. Cottep-Howells and A.A. Meharg. 2002b. Arsenic uptake and accumulation in rice (Oryza sativa L.) irrigated with contamination water. Plant and Soil. 240(2): 311319.

Adriano, D.C. 2001. Trace elements in terrestrial environments. Springer-Verlag, $2^{\text {nd }}$ end., New York, P. 867.

Carbonell-Barrachina, A.A., F. Burlo-Carbonell and J. Mataix-Beneyto.1995. Arsenic uptake, distribution and accumulation in tomato plants: effect of arsenic on plant growth and yield. J. Plant Nutri. 18: 1237-1250.

Carbonell-Barrachina, A.A., M.A. Aarabi, R.D. DeLaune, R.P. Gambrell and W.H. Patrick. 1998. The influence of arsenic chemical form and concentration on Spartina patens and Spartina alterniflora growth and tissue arsenic concentration. Plant Soil.198:33-43.

Cox, M.S., P.F. Bell and J.L. Kovar. 1996. Different tolerance of canola to arsenic when grown hydroponically or in soil. J. Plant Nutri. 19: 1599-1610. 
Dixon, H.B.F. 1997. The biochemical action of arsenic acids especially as phosphate analogues. Advances in Inorganic Chemistry. 44: 191-227.

Geng, C.N., Y.G. Zhu, Y. Hu, P. Williams and A.A. Meharg. 2006. Arsenate causes differential acute toxicity to two P-deprived genotypes of rice seedlings (Oryza sativa L.). Plant Soil. 279: 297-306.

Ghosh, M. 2011. Effect of sodium arsenate and arsenate-phosphorus interaction on germination, seedling growth and some biochemical parameters of rice, wheat, maize and mung bean. M.Sc. Thesis (Unpublished). Department of Botany, Jahangirnagar University, Dhaka, Bangladesh. pp. 24-26.

Gomez, K.A. and A.A. Gomez. 1984. Statistical Procedures for Agricultural Research. $2^{\text {nd }}$ edn. John Wiley, New York.

Haq, S.M.I, A. Rahman, S. Sultana and R. Naidu. 2003. Extent and severity of arsenic contamination in soils of Bangladesh. In: Fate of Arsenic in the Environment (ed. F. Ahmed, M. A. Ali and Adeal, Z.). BUET-UNU International Symposium, Dhaka. pp. 6984.

Hertley-Whitaker, J., G. Ainswort and A.A. Meharg. 2001. Copper and arsenate induced oxidative stress in Holcus lanatus L. Clones with different sensitivity. Plant Cell Environ. 24: 713722.

Hossain, M.B., M. Jahiruddin, G.M. Panaullah, R.H. Loeppert, M.R. Islam and J.M. Duxbury. 2008. Spatial variability of arsenic contamination in soils and plants, and its relationship with iron, manganese and phosphorus. Environment Pollution. 156: 739-744.

Islam, M. R. and M. Jahiruddin. 2010. Effects of arsenic and its interaction with phosphorus on yield and arsenic accumulation in rice. 19th World Congress of Soil Science, Soil Solutions for a Changing World,1- 6 August 2010, Brisbane, Australia. pp.12-25.

Jahan, L., S. Haque, S.M. Ullah and M.G. Kibria. 2003a. Effects of arsenic on some growth parameters of rice plant. Dhaka Univ. J. Biol. Sci. 12(1): 71-77.

Kang, L.J., X.D. Li, J.H. Liu and X.Y. Zhang. 1996. The effect of arsenic on the growth of rice and residues in a loam paddy soil. J. Jilin. Agric. Univ. 18(3): 58-61.

Machlachalan, S. and S. Zalik. 1963. Plastid structure, chlorophyll concentration and free amino acid composition of a chlorophyll mutant of barley. Can J. Bot. 41: 1053-1062.

Marin, A.R., P.H. Masscheleyn and J. W.H. Patrick.1992. The influence of chemical form and concentration of arsenic on rice growth and tissue arsenic concentration. Plant and Soil. 139: $175-183$.

McKinney, G. 1940. Criteria for purity of chlorophyll preparations. J. Biol. Chem. 132: 91-109.

Meharg, A.A. and M.R. Macnair. 1992. Polymorphism and physiology of arsenate tolerance in $H$. lanatus L. from an uncontaminated site. New Phytologist. 146: 219-224.

Miteva, E. and M. Merakchiyska. 2002. Response of chloroplasts and photosynthetic mechanism of bean plants to excess arsenic in soil. Bulg. J. Agric. Sci. 8: 151-156.

Panaullah, G.M., T. Alam, M.B. Hossain, R.H. Loeppert, J.G. Lauren, C.A. Meisner, Z.U. Ahmed and J.M. Duxbury. 2009. Arsenic toxicity to rice (Oryza sativa L.) in Bangladesh. Plant and Soil. 317: 31-39.

Peryea, F.J. 1998. Phosphate starter fertilizer temporarily enhances soil arsenic uptake by apple trees grown under field conditions. Hort. Sci. 33: 826-829.

Qafoku, N.P., U. Kukier, M.E. Sumner, W.P. Miller and D. E. Radcliffe. 1999. Arsenate displacement from fly ash amended soils. Water, Air and Soil Pollution. 114: 185-198.

Raghothama, K.G. 1999. Phosphate acquisition. Annual Rev. Plant Physiol. Mol. Biol. 50: 665693. 
Rahman, M.A., M.M. Rahman, M.A.M. Miah and H.M. Khaled. 2004. Influence of soil Arsenic Concentrations in rice (Oryza sativa L.). J. Subtrop. Agric. Res. Dev. 2(3): 24-31.

Ravenscroft, P., W.L. Burgess, K.M. Ahmed, M. Burren and J. Perrin. 2005. Arsenic in groundwater of the Bengal Basin, Bangladesh: Distribution, field relations and hydrogeological setting. Hydrogeol. J. 13: 727-751.

Roberts, L.C., S.J. Hug, J. Dittmar, A. Voegolin, G.C. Saha, M.A. Ali, A.B.M. Badruzzaman and R. Kretzschmar. 2007. Spatial distribution and temporal variability of arsenic in irrigated rice fields in Bangladesh. I. Irrigation Water. Environ. Sci.Technol. 41: 5960-5966.

Shaibur, M. R., T. A. Adjadeh and S. Kawai. 2013. Effect of phosphorus on the concentrations of arsenic, iron and some other elements in barley grown hydroponically. J. Soil Sci. Plant Nutr. 13(1): 87-98.

Sharma, I. and I.S. Travlos. 2012. Phosphate supply as a promoter of tolerance to arsenic in pearl millet. International Journal of plant production. 6(4):443-456.

Sneller, F E C., L. M. Van Heerwaarden, F. J. Kraaijeveld-Smit, W.M. Ten Bookum, P. L. M. Koevoets, H. Schat and J. A.C. Verkleij. 1999. Toxicity of arsenate in Silene vulgaris, accumulation and degradation of arsenate-induced phytochelatins. New Phytol. 144: 223-232.

Ullah, S.M. 1998. Arsenic contamination of groundwater and irrigated soils of Bangladesh. In Abstracts: Int. conf. Arsenic pollution of Groundwater in Bangladesh: Causes, Effects and remedies, 8-12 February 1998. DCH, Dhaka. P.133.

Van. A.F. and H. Clijsters. 1990. Effects of metal on enzyme activity in plants. J. Plant Cell Environ. 13: 195-206.

Wang, L. and G. Duan. 2009. Effect of external and internal phosphate status on arsenic toxicity and accumulation in rice seedlings. J. Environ. Sci. 21: 346-351.

Yu, T. Q., L. N. Chai and Z. P. Liu. 1995. Expression of the soluble protein in water-stressed wheat seedlings and the drought-resistant proteins. J. Beijing Agric. College. 10(1): 26-31.

(Received revised manuscript on 20 March 2014) 